DOI https://doi.org/10.18551/rjoas.2021-01.11

\title{
DIVERSITY OF PARACITOID INSECTS IN VARIOUS AGE OF RICE PLANTS IN PIDIE AND PIDIE JAYA DISTRICTS, ACEH PROVINCE, INDONESIA
}

\author{
Mukhtar Umar, Husni ${ }^{\star}$ \\ Master's program of of Agrotechnology, Faculty of Agriculture, Syiah Kuala University, \\ Banda Aceh, Indonesia \\ *E-mail: husnimusannif@unsyiah.ac.id
}

\begin{abstract}
This study aims to determine the diversity of parasitoids in lowland rice plants in Pidie and Pidie Jaya districts, Aceh Province, Indonesia. The parameters observed included the number of individuals, community structure, wealth index, diversity index and evenness index and parasitoid community similarity. The research was conducted from July to December 2018 in Glumpang Tiga District and Mutiara District, Pidie Regency and Meureudu District and Meurah Dua District, Pidie Jaya Regency using a survey method with a purposive sampling technique. The insect traps used are sweeping net and pit fall trap. The results showed that both Pidie and Pidie Jaya districts indicated that the species richness index, diversity index and evenness index of parasitoid insects increased with increasing age of lowland rice plants. The lowest average species richness index at the age of 30 DAP was 1.51 and the highest was at the age of 60 DAP by 2.05; the lowest average diversity index at the age of 30 DAP was 1.24 and the highest was at the age of 45 DAP at 2.02; The lowest average of the evenness index at the age of 30 DAP was 0.55 and the highest was at the age of 45 DAP at 0.92 .
\end{abstract}

\section{KEY WORDS}

Parasitoid diversity, community structure, number of individuals, community similarity, family wealth.

Rice (Oryza sativa L.) is the main food crop of Indonesian society, but its availability is not sufficient for the needs of the Indonesian population. Sembel (1991) states that rice plants can grow well in tropical and subtropical areas, especially in places that are irrigated throughout the year or that have high enough rainfall. Indonesia is an agricultural country with most of its people working as rice farmers, both on dry and wetlands. Rice is a strategic commodity because it is related to economic life as well as influencing the social and political conditions of society, so rice plays an important role in the economy in Indonesia (Sembel, 1991).

Rice consumption has increased and is directly proportional to the population, almost half of the world's population chooses rice as the main food. Efforts to increase rice production can be done by means of intensification, extensification and diversification of agriculture. However, in an effort to increase rice production, various obstacles were found, namely the presence of pests. Pests are one of the obstacles in maintaining and increasing food production in Indonesia, especially lowland rice plants (Ardjanhar and Negara, 2011). The paddy field ecosystem is theoretically an unstable ecosystem. The stability of the rice field ecosystem is not only determined by the diversity and structure of the community, but also by the characteristics of the components and the interactions between ecosystem components also influence it. The results of the research on habitat studies showed that no less than 700 species of insects including parasitoids and predators were found in the rice field ecosystem with no pests. The results of this study indicate that the rice field community is diverse (Untung, 1992).

The vegetative growth phase is generally a phase that is very vulnerable to pests, especially insect pests. In the vegetative phase, the insect pest population usually increases (out break), but the increase in insect population is usually followed by an increase in the population of natural enemies, such as parasitoid insects and predators. Therefore, a study 
(research) is needed to see the diversity of parasitoid insects. at various age levels of paddy fields in Pidie and Pidie Jaya districts.

\section{MATERIALS AND METHODS OF RESEARCH}

This research was conducted from July to December 2018. Parasitoid samples were taken in Glumpang Tiga and Mutiara Districts, Pidie District and Meureudu District and Meurah Dua District, Pidie Jaya Regency. Parasitoid identification was carried out at the Laboratory of Biological Control, Faculty of Agriculture, Syiah Kuala University. This study used a survey method, focused on the diversity of Hymenoptera parasitoid. Insect sampling was carried out using a purposive sampling method.

The sampling locations were in two districts, namely Pidie Regency and Pidie Jaya Regency. Two villages were selected in each sub-district, two rice fields were taken in one village, then each sample land was divided into five sub-samples. Overall, there are 16 sample plots or 80 sub-samples which are used as sampling locations in the field. The rice fields selected as sample areas are paddy fields with a minimum area of $1,000 \mathrm{~m}^{2}$. From this land, 5 sub-sample lands were selected with a size of each sub-sample with a minimum size of $20 \mathrm{~m} 2$. Determination of sub-samples using a diagonal slice method on a predetermined sample area (Figure 1).

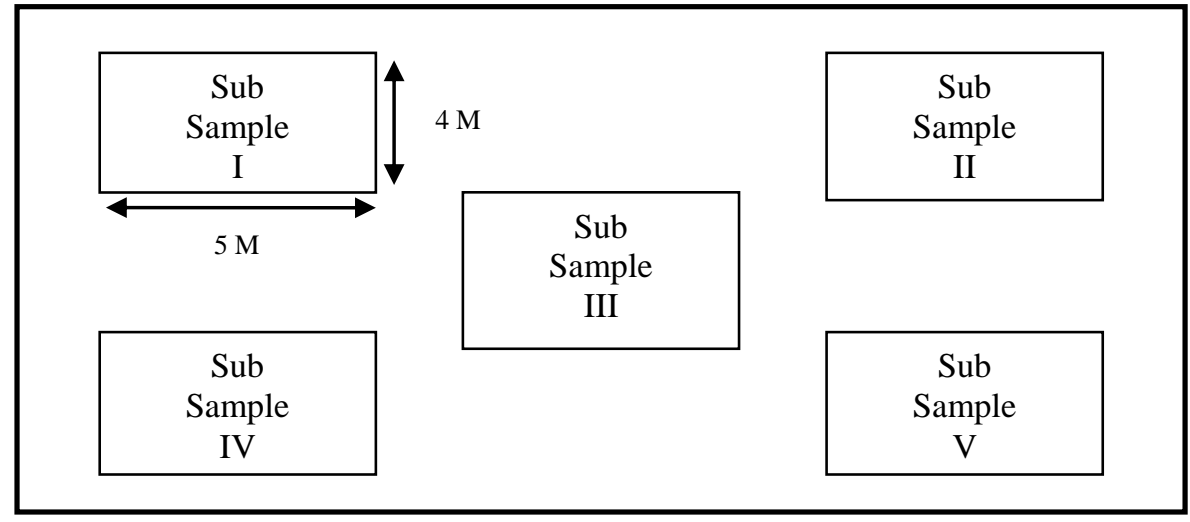

Figure 1 - Locations for Sampling from Sample

Insect sampling was carried out twice in the vegetative phase (30 and $45 \mathrm{DAP}$ ), and once in the generative phase (60 DAP). Sampling was done by collecting all groups of insect species found in each sub-sample using a sweeping net and pit fall trap. The insect samples were then put into a plastic tube, then all samples were taken to the laboratory for the sorting process. As for the identification, it was carried out at the Laboratory of Pests and Plant Diseases, Faculty of Agriculture, Gadjah Mada University.

The variables observed in this study included the number of parasitoid individuals, composition and structure of the parasitoid community, wealth index, diversity, and evenness of the number of individuals and the similarity of the Hymenoptera parasitoid community.

\section{RESULTS AND DISCUSSION}

Parasitoid populations that have been collected from rice fields in Pidie and Pidie Jaya districts can be seen in Figure 2.

Figure 2 shows that the number of parasitoids in the growth of lowland rice plants in Pidie Regency at the age of 30 DAP was 236 individuals, at 45 DAP there were 127 individuals and at the age of 60 DAP was 71 individuals, but the number of individuals in the growth of lowland rice plants in Pidie Jaya Regency, the age of 30 HST is 335 individuals, the age of 45 HST is 169 individuals and at the age of 60 DAP is 103 individuals. 
The parasitoid community is influenced by vegetation, the availability of food and a host for laying eggs. Diverse vegetation will provide more diverse habitats so that there will be more types of insects and specialist parasitoids (Godfray, 2000).

The low number of individuals and the number of parasitoid families in lowland rice plants aged 45 DAP and 60 DAP is thought to be influenced by the intensive application of synthetic pesticides. The use of these pesticides is carried out to maintain the growth of immature plants from pest attacks, because young plants are still susceptible to pests and diseases as well as very high growth of weeds so that they can reduce the parasitoid population.

The use of pesticides and other chemicals can affect the presence of parasitoids both dead and immigrating. Osama and Mohammed (2012) also stated that herbicides can limit the efficiency of parasitoids and affect parasitoid activity by destroying food sources, eliminating micro-habitats or direct killing and changing habitats.

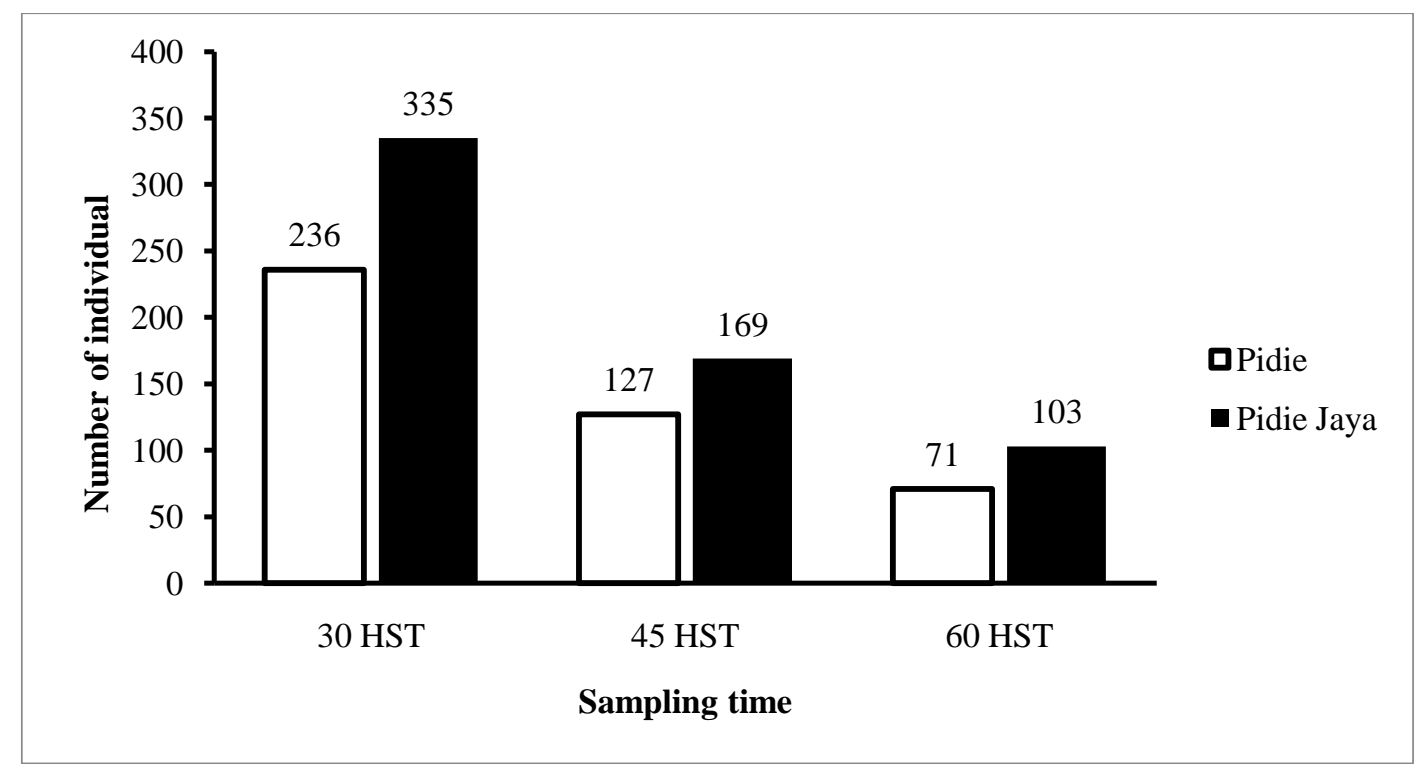

Figure 2 - Number of individual Hymenoptera parasitoids based on age of lowland rice plants

This is due to the inability of these parasitoids to detoxify the insecticide (Pedigo, 1991). Hidayani et al. (2013) stated that insecticides kill parasitoids directly when applied or due to contact with pesticide residues found on the leaves when female imago is looking for its host.

Parasitoid spends most of its life in parasitizing its host to obtain food from or lay eggs on its host so that the host dies. Supporting factors for parasitoid life in the producing plant ecosystem. Parasitoids in the field are generally more susceptible to insecticides than their hosts (Hidrayani et al., 2013).

The results of this study indicate that these two families are very dominant in the ecosystem of rice plants in Pidie and Pidie Jaya districts. The diversity of other insects also affects the diversity of existing parasitoids. Other insects are hosts for parasitoids and prey for predators. The higher the diversity of insects in a habitat, the higher the diversity of parasitoids and predators in the habitat. This is related to the fulfillment and fulfillment of food for these parasitoids (Pebriyanti et al., 2016). According to Sahari (2012), the diversity of parasitoids always follows the diversity of their hosts, which are generally phytophagic insects, the diversity of phytophage insects depending on the availability of host plants in the ecosystem.

Based on Figure 3 and Figure 4, it is known that the ichneumonidae, Tachinidae and Braconidae families are the types of families with the highest percentage found in rice plants in Pidie and Pidie Jaya Districts, this indicates that the Ichneumonidae and Braconidae families are potential families as parasitoid. This is thought to be due to sufficient host 
availability. The ichneumonidae family itself has a host in the form of larvae from Hymenoptera or larvae of the Lepidoptera Order (Goulet and Hubber, 1993).

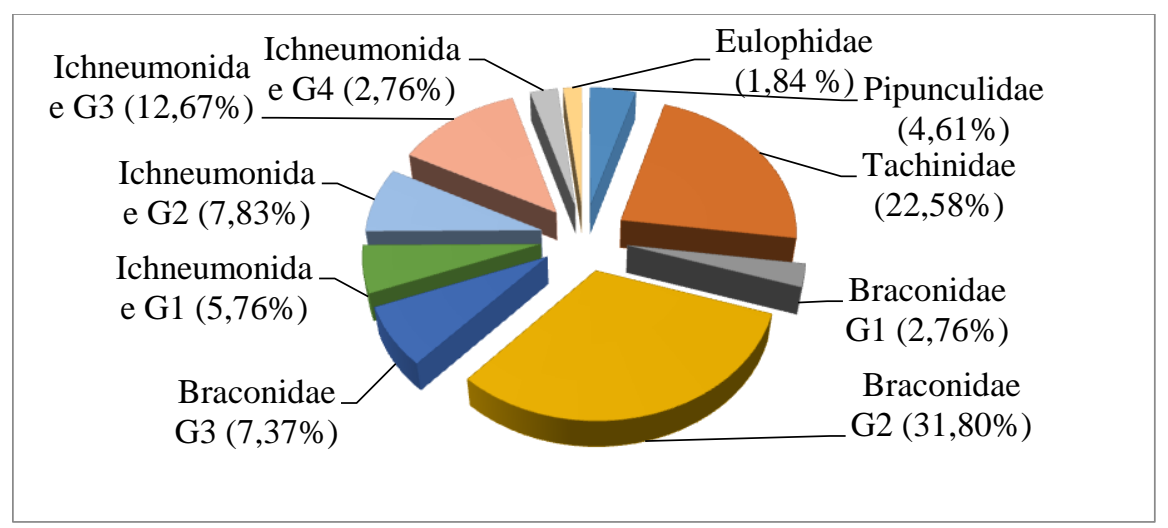

Figure 3 - Percentage of individual Hymenoptera parasitoid collected from lowland rice plants in Pidie District

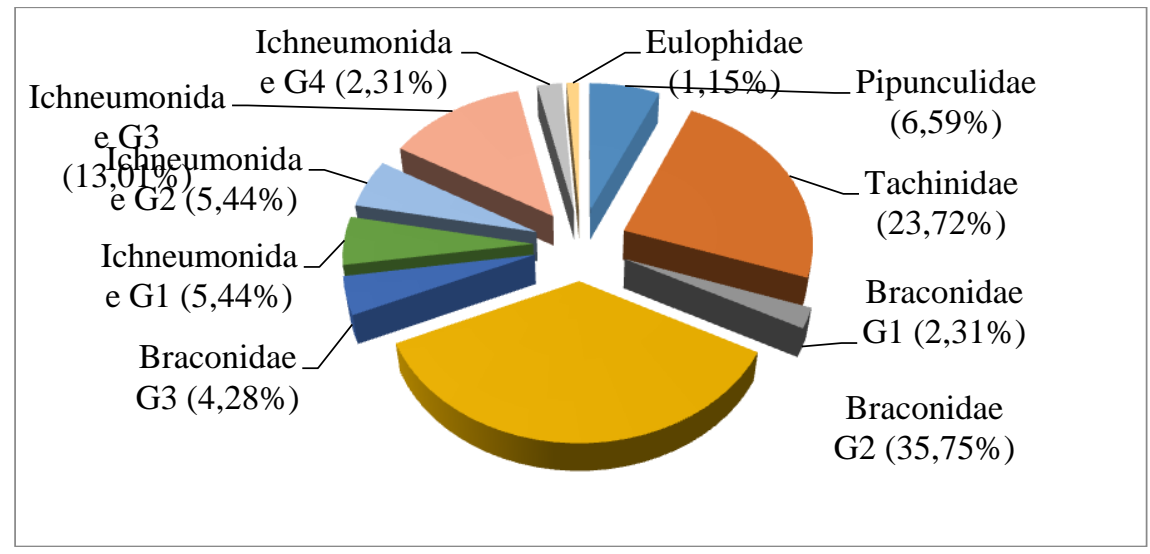

Figure 4 - Percentage of individual Hymenoptera parasitoid collected from rice plants in Pidie Jaya Regency

At the age of 30 DAP plants, the highest wealth of parasitoid families in Pidie and Pidie Jaya Regencies was found in each family of Braconidae (G2) at $31.80 \% ; 35.75 \%$ and Tachinidae $22.58 \% ; 23.72 \%$, with increasing time the population continued to decline at the age of 45 DAP and 60 DAP. This is thought to be due to climate factors that are too extreme, the application of pesticides and herbicides is more intensive and the presence of nectants that cause stem borer pests to die so that the source of the food chain from these parasitoids is cut off.

The results showed that the richness, diversity and evenness of parasitoid insects on the growth of lowland rice plants aged 30 DAP, 45 DAP and 60 DAP in Pidie and Pidie Jaya Regencies can be seen in Figure 5.

Figure 5 shows that the total parasitoid species richness index increases with increasing age of the rice plants, the species richness index of rice plants aged 30,45 and 60 DAP respectively $1.65,1.86$ and 2.11 . This is thought to have reduced the use of pesticides in Pidie District, but in Pidie Jaya District, the number of parasitoid species richness indexes increased with increasing age of rice plants, the species richness index of rice plants aged 30,45 and 60 DAP respectively $1.38,1.75$. and 1.94 presumably because the environmental conditions support the development and availability of sufficient hosts for the Hymenoptera parasitoids, the more hosts for the parasitoid, the more parasitoid found in the area. This is in line with the results of research by Moningka et al. (2012) stated that the level of wealth of insects as natural enemies of parasitoids increases with increasing age of rice plants. The wealth index value is influenced by the number of all individuals found in an 
area. These environmental conditions have not supported the development and the availability of sufficient hosts for the Hymenoptera parasitoid, the more hosts for the parasitoids, the more parasitoid found in the area. The wealth index value is influenced by the number of all individuals found in an area.

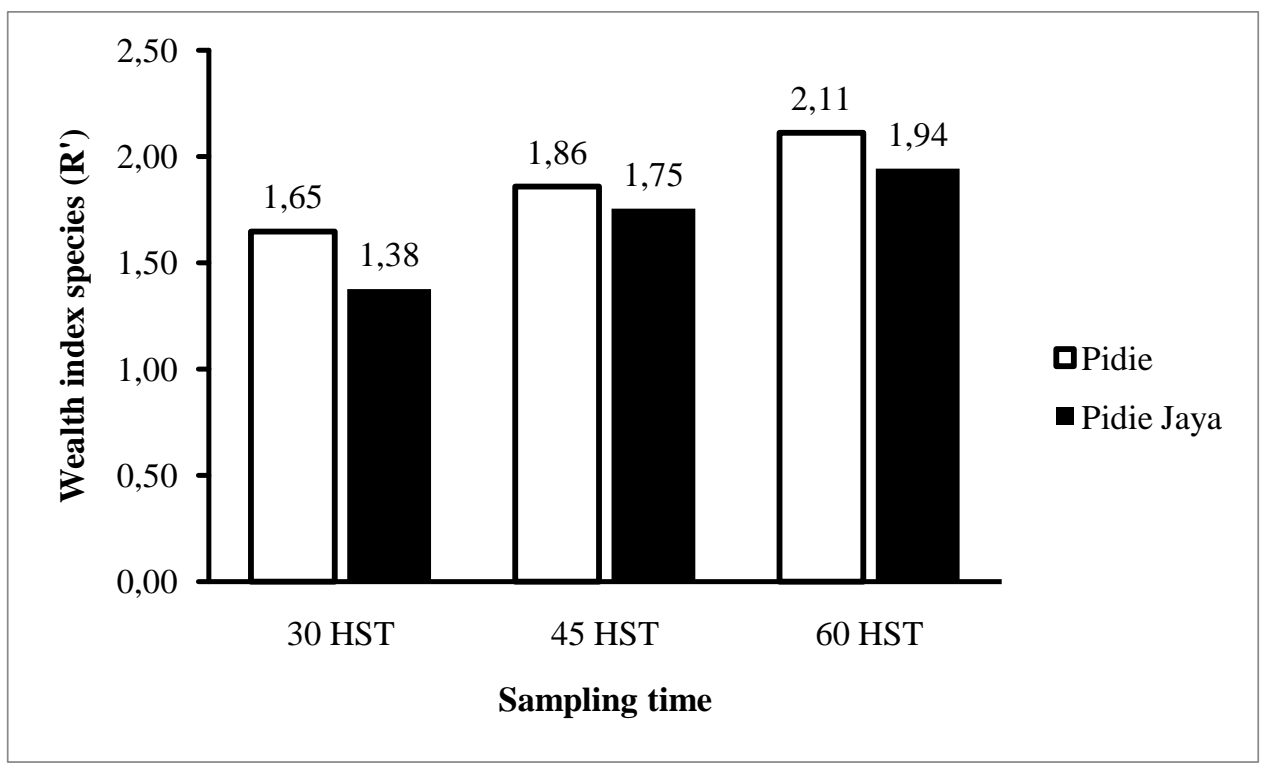

Figure 5 - Species Wealth Index of Parasitoid in Rice Fields

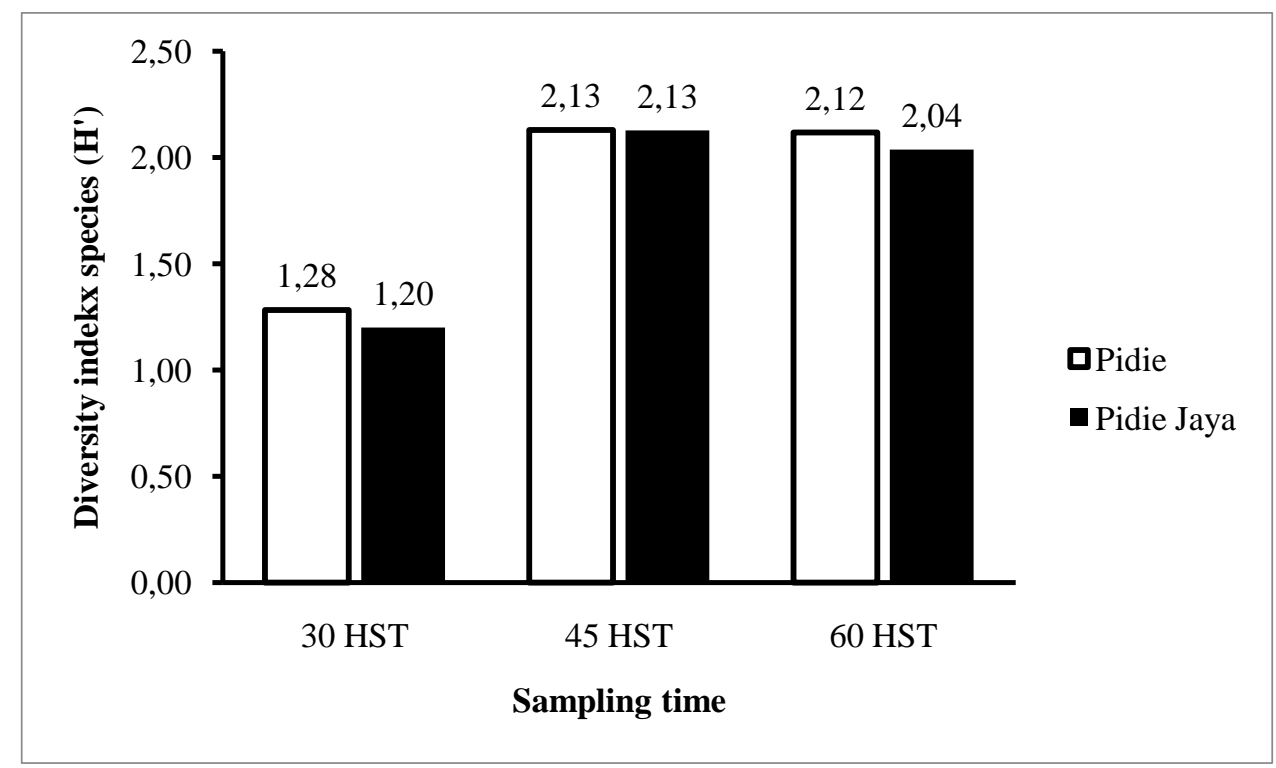

Figure 6 - Diversity Index of Parasitoid Species in Rice Paddy Plants

Figure 6 shows that the lowest species diversity index of Hymenoptera parasitoid was found in the growth of lowland rice plants aged 30 DAP at 1.28, while the highest at the age of 45 DAP was 2.13 and at the age of 60 DAP was 2.12. Based on the parasitoid species diversity index in Pidie District, it ranges from 1.28 to 2.13 , the criteria for the diversity index based on the results analyzed using the Shannon-Wiener Diversity Index are classified as moderate criteria.

This is in accordance with Michael's statement (1995), there are 3 criteria for diversity. type of insect, that is, if $\mathrm{H}^{\prime}<1$ means that the diversity of insects is low, if $\mathrm{H}^{\prime}=1,3$ means that the diversity of insects is classified as moderate, if $\mathrm{H}>3$ means that the diversity of insects is high. This can occur because there are no food sources that are needed by insects, both insects, pests and parasitoids. Michael (1995) said that the more heterogeneous a physical 
environment is, the more complex the scattered flora and fauna communities will be and the higher the diversity of its species.

The diversity of Hymenoptera parasitoid species is influenced by various environmental factors, including spatial diversity, habitat type, season and environmental stability and productivity. (Rosenzweig, 1995).

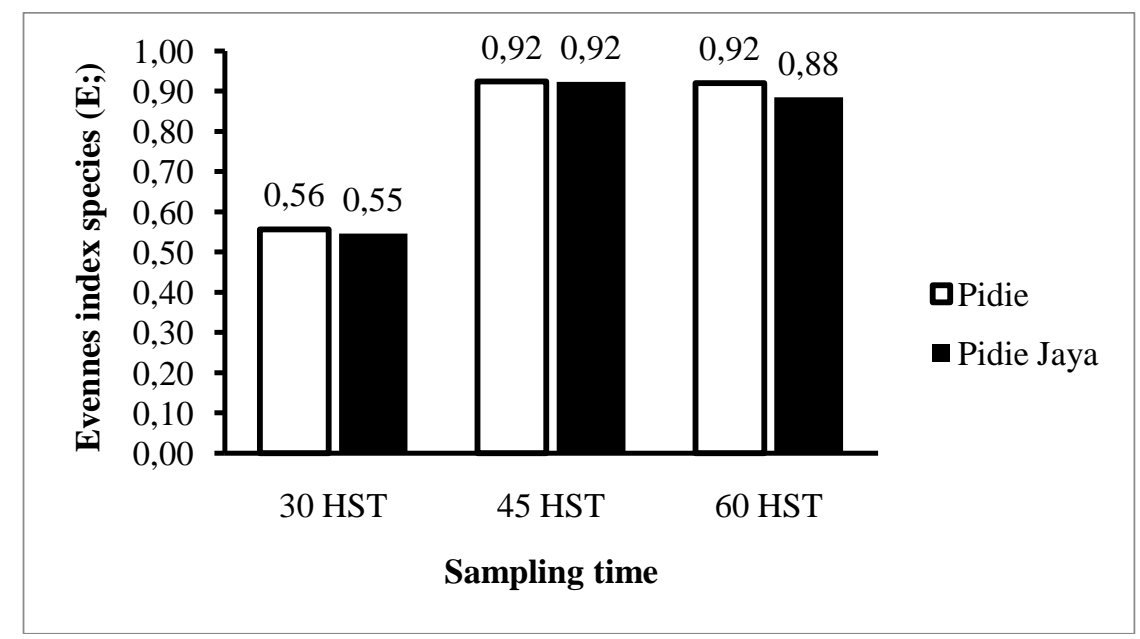

Figure 7 - Evenness Index of Parasitoid Species in Rice Paddy Plants

Figure 7 shows that the lowest evenness index of Hymenoptera parasitoid species was found in the growth of lowland rice plants aged 30 DAP at 0.56, while the highest at the age of 45 DAP and age 60 DAP was 0.92 . Based on the parasitoid species diversity index in Pidie District, it ranges from $0.56-0.92$, the criteria for the evenness index based on the results were analyzed using the equation according to Pielou (1977: 308) at the age of 30 DAP is quite evenly distributed and at the age of 45 DAP and $60 \mathrm{HST}$ is classified as almost evenly critical. The evenness index value tends to lead to zero if the observed community is dominated by one species (Heong et al., 1991), but the lowest evenness index of Hymenoptera parasitoid species in Pidie Jaya Regency was found in the growth of lowland rice plants aged 30 DAP at 0,55 while the highest was at the age of 45 HST amounting to 0.92. Based on the parasitoid species diversity index ranging from 0.55 to 0.92 , the evenness index criteria based on the results were analyzed using the equation according to Pielou (1977) at the age of 30 DAP is classified as fairly evenly critical and at the age of 45 DAP and 60 DAP are classified as almost evenly critical .

Based on the results of the analysis of the similarity of the parasitoid community using the sorensen similarity index, it is known that the similarity of the Hymenoptera parasitoid community between the two districts is very high at $100 \%$.

Table 1 - Similarity Index of Parasitoids in Rice Plants aged 30 DAP, 45 DAP and 60 DAP in Pidie and Pidie Jaya Regencies

\begin{tabular}{cccccc}
\hline \multirow{2}{*}{ Location } & \multirow{2}{*}{ Total Insects (Species) } & \multicolumn{2}{c}{ The same kind of insect (Species) } & \multicolumn{2}{c}{$\begin{array}{c}\text { Similarity Index Value } \\
(\%)\end{array}$} \\
\cline { 2 - 5 } PR & 10 & 30 DAP & 45 DAP & 60 DAP & \\
PJR & 10 & 9 & 10 & 10 & 100 \\
\hline
\end{tabular}

Note: $P R=$ Pidie Regency and PJR = Pidie Jaya Regency .

Soerinegara and Indrawan (1998) state that the Similarity Index value ranges from 0\% - $100 \%$. The closer to $100 \%$ means that the ecosystem condition of the two samples being compared is getting the same if it is close to $0 \%$, then the conditions of the two samples being compared are getting different. Mawazin and Subiakto (2013) stated that the higher the species similarity index value, the fewer different species composition and vice versa. The 
composition of the two communities is said to have the same level of composition if it has the same species index value $>50 \%$.

From Table 1, it is known that the similarity index value of the Hymenoptera parasitoid between the two observation areas is classified as moderate, namely $100 \%$ (Sorensen index value 0.1 . The species composition of a community is influenced by environmental conditions so that disturbances in environmental conditions can affect its species composition.

\section{CONCLUSION}

The number of parasitoids individuals in the growth of lowland rice plants in Pidie Regency at the age of 30 DAP was 236 individuals, at 45 DAP was 127 individuals and at the age of 60 DAP was 71 individuals, but the number of individuals on the growth of lowland rice plants in Pidie Jaya Regency was aged 30. HST is 335 individuals, age 45 DAP is 169 individuals and at age 60 DAP is 103 individuals. The average species richness index ranged from 1.51 - 2.05 (low richness), the average diversity index ranged from $1.24-2.02$ (moderate diversity) and the average evenness index ranged from $0.55-0,92$ (almost evenly). The results showed that both Pidie and Pidie Jaya districts indicated that the species richness index, diversity index and evenness index of parasitoid insects increased with increasing age of lowland rice plants.

\section{REFERENCES}

1. Ardjanhar A. and A. Negara. 2011. Tingkat Parasitasi and Jenis Parasitoid Telur Penggerek Batang Padi Putih di Kabupaten Sigi Sulawesi Tengah.

2. Godfray HCJ. 1994. Parasitoid: Behavioral and Evolutionary Ecology. New Jersey (US): Pricenton University Press.

3. Goulet H, Huber JT. 1993. Hymenoptera of the World: An Identification Guide to Familes. Ottawa: Research Branch Agriculture Canada Publication

4. Heong, K.L., G.B. Aquino., and A.T. Barrion. 1991. Arthropod community strucuture of rice ecosystem in the Philippines. Bulletin of Entomological Research 81: 47-416.

5. Hidrayani R, Rusli, and YS Lubis. 2013. Keaneragaman spesies parasitoid telur hama Lepidoptera and parasitasinya pada beberapa tanaman di Kabupaten Solok, Sumatera Barat. Jurnal Natur Indonesia. Vol. 15 no. 1; 9 - 14.

6. Magurran AE. 1988. Ecological Diversity and Its Measurement. New Jersey: Princeton University Press.

7. Michael, P. 1995. Metode Ekologi untuk Penyelidikan Lapangan and Laboratorium. Terjemahan Yanti R. Koester. UI-Press, Jakarta.

8. Moningka, M., Tarore, D., and Krisen, J. 2012.Keragaman Jenis Musuh Alami pada Serangga Hama Padi Sawah di Kabupatean Minahasa Selatan. Jurnal Entomologi. Jurusan Hama and Penyakit Tumbuhan. FP Unsrat Manado

9. Osama, A E S and Mohamed, T F E. 2012. Side-Effect of Certain Herbicides on Egg Parasitoid Trichogramma evanescensn (West.) (Hymenoptera: Trichogrammatidae). Department of Plant Protection, Faculty of Africulure, Al-Azhar University, Cairo. Academic ournal of Entomology 5 (1): 01-10.

10. Pedigo, L.P. 1991. Entomology and Pest Management. Macmillan Publishing Company.

11. Rosenzweig, ML. 1995. Species diversity in space and time. Cambrige University Press.

12. Sahari B. 2012. Struktur komunitas parasitoid Hymenoptera di perkebunan kelapa sawit, Desa Pandu Senjaya, Kecamatan Pangkalan Lada, Kalimantan Tengah [Disertasi]. Bogor (ID): Institut Pertanian Bogor.

13. Sembel. D. T., 1991. Beberapa Serangga Hama Pada Tanaman Padi and Jagung. Proyek Pengembangan Perguruan Tinggi Unsrat Manado. 71 hal.

14. Soerianegara, I. and Indrawan, A. 1998. Ekologi Hutan Indonesia. Laboratorium Ekologi Hutan Fakultas Kehutanan Institut Pertanian Bogor. Bogor

15. Untung K. 1992. KonsepPengendalian Hama Terpadu, Andi Offset. Yogyakarta. 